\title{
TO I.A. KARYAZIN, SCIENTIFIC EDITOR OF THE JOURNAL RUSSIAN METALLURGY (METALLY)
}

PACS number: 01.60.+q

DOI: $10.1134 / \mathrm{S} 0036029509010169$

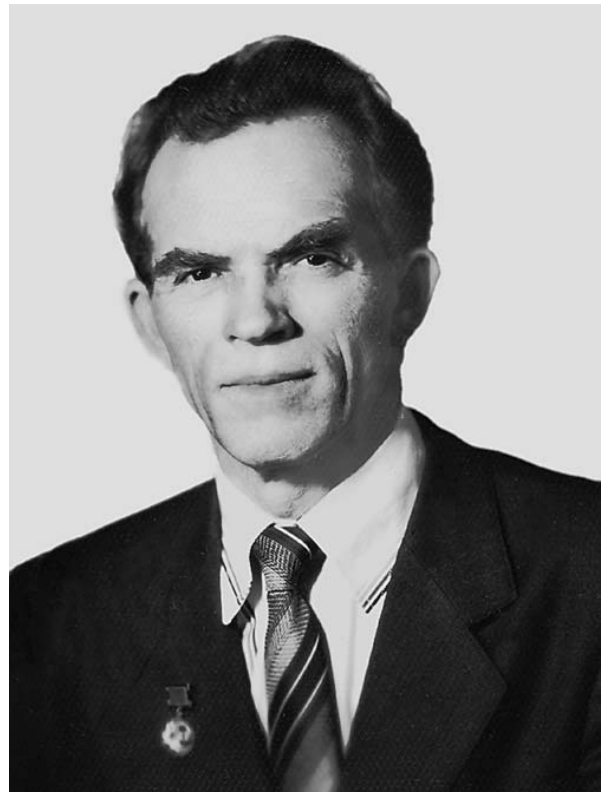

\section{Dear Irinarkh Aleksandrovich!}

The administration of the Baikov Institute of Metallurgy and Materials Science, Russian Academy of Sciences, the Editorial Board, and the staff of the journal Russian Metallurgy (Metally) heartily congratulate you on your brilliant jubilee- 50 years of work as the Scientific Editor and the Executive Editor-in-Chief of this journal.

You are a famous expert in the field of the electrothermy of iron-titanium ores and the complex use of mineral raw materials, and you was awarded the State Prize of the USSR in 1981 and the Bardin Prize of the Russian Academy of Sciences in 1998 for your scientific achievements. However, recognizing the role of scientific and technological information for the development of science and the importance of a periodic scientific journal (which reflects the achievements in metallurgy and materials science) for the prestige of the Baikov Institute of Metallurgy and Materials Science and the Russian Academy of Sciences, in 1959 you decided to combine your scientific activity with work at the journal Metally.

Due to your strict and careful work on editing scientific articles, you have received the recognition and due respect of metallurgists and physical metallurgists in our country and abroad.

Three hundred issues of the journal were published in 50 years, and each issue contains part of your daily diligent work intended to maintain a high impact factor of the journal both in Russia and abroad. One of the indices of your work is an annual increase in the subscription to the English version of the journal.

Dear Irinarkh Aleksandrovich! Although life often created problems, you retain warmth, kindness, desire to help people, high working efficiency, and belief in the future due to your high strength of mind. Please, retain these brilliant features for many years to come.

We wish you vivacity, good health, and new achievements.

Director of the Baikov Institute of Metallurgy and Materials Science, Academician K.A. Solntsev

Editor-in-Chief of the journal Russian Metallurgy (Metally), Academician O.A. Bannykh 